Film Festival Origins and Trajectories, March 2016 (volume 14, number 1)

This special issue of NRFTS explores the genesis of festivals, in different countries, to trace the distances festivals have travelled from their origins, how changes are sometimes intentional and at other times the results of socio-political and economic transformations.

\title{
Constraints and Possibilities: Lima Film Festival, Politics and Cultural Formation in Peru
}

Sarah Barrow, University of Lincoln, Lincoln, UK

sbarrow@lincoln.ac.uk

DOI of paper: 10.1080/17400309.2015.1109354. Once published online (18 Nov), it will be available at the following permanent link: http://dx.doi.org/10.1080/17400309.2015.1109354

\section{$\underline{\text { Abstract }}$}

The Festival de Cine de Lima (Lima Film Festival) launched in 1997 and, from humble beginnings, each year now introduces around 300 films to diverse audiences across the Peruvian capital and beyond. In 2014, for the first time in its history, four of the nineteen films selected for the feature competition were made by Peruvian directors, signalling a growing recognition of national talent by programming panels and critics that had tended to look beyond national borders for inspiration and challenge. Despite the relative paucity of coordinated film production activity in Peru, it is argued here that the flourishing of Lima Film Festival provides evidence of a deep sense of film appreciation that conveys a commitment to all forms of cinema. This essay reflects critically on the local, national and international impact of this Festival, its influence on the development of film policy in Peru, and explores its role as a 'key building block of film culture' (Iordanova, 2013) across a complex national framework.

\section{$\underline{\text { Keywords }}$}

Lima - Film Festival - political violence - Shining Path - independent cinema 


\section{Introduction}

The Festival de Cine de Lima (Lima Film Festival) celebrated its eighteenth edition in August 2014 by bringing over 300 films - including some of the most exciting new works from Latin America - to audiences across the capital of Peru. For the first time in its history, four of the nineteen films selected for competition were made by Peruvian directors, signaling not only a growth of local aspiration and talent, but also a clear recognition of that talent by programming panels that had tended since its inception to look beyond national borders for inspiration. Despite the relative paucity of film production activity in Peru in comparison even with many of its Latin American neighbors, and the lack of any robustly and coherently coordinated and funded film industry, the establishment and endurance for almost two decades of an increasingly high profile film event provides evidence of a sense of the broader film culture - including publications, workshops, community-based initiatives and social media platforms - that has developed significantly in Peru since the 1960s. As was the case with many other Latin American nations, this was the decade when cine-clubs emerged as popular social hubs, designated government-sponsored funding initiatives and legislation were first established and serious film criticism started to appear. As Jeffrey Middents (2011) contends in his project on Peruvian film journalism, for a variety of socio-economic, cultural and political reasons, film culture has become more important and prominent in Peru than film production; this essay explores the way that the Lima Film Festival has contributed to the evolution of a national film culture over the last two decades, its impact on shaping the views of audiences towards independent Latin American cinema, and its influence on the outputs and ambitions of those Peruvian filmmakers whose works have succeeded in finding an exhibition spot at this increasingly prestigious event. It addresses the apparent paradox of the launch of such an event at a time of economic, social, cultural and political crisis, and argues that this Festival has played a prominent role in shaping and supporting film 
production in Peru, has grown increasingly confident in terms of the range of films it selects, and has itself grown in stature and impact on the international festival circuit. It argues that while the existence of film production in Peru has been described, at best, as intermittent, scarred by instability and a creative response to crisis (Bedoya 1997, 306-8), the existence, survival and success of a festival such as this one is part of an ongoing and enduring national culture of artistic and cinematographic appreciation.

The Festival's origins were sparked by a desire on the part of several influential cultural leaders at that time to mark the eightieth anniversary of the Cultural Centre of the Catholic University of Peru (PUCP), with an event that was supported by the national government through Promperú (the Commission for Promotion of Peru through Export and Tourism), UNESCO and a range of cultural and commercial organizations. ${ }^{1}$ This eleven-day celebration in August 1997 included screenings of twenty-one features and twenty-eight short films from ten Latin American nations, and attracted over 15,000 spectators. Eight hundred more attended a range of seminars and debates that served as 'theoretical complement' (Galiano 1998, 7) to the screenings, and a further three hundred attended a linked three-day event, the first of its kind, in the southern city of Arequipa. In setting up this celebration, the University and its Cultural Centre were to a large extent affirming their position as leaders in the exposition of national art and culture, and by choosing to place film at the heart of those celebrations, they took a stand on behalf of art cinema at a time when the government could not, or would not, do so for reasons outlined below. As the University’s Rector Salomón Lerner declared resolutely and with typical flourish in his speech to mark the closing ceremony of the first Festival, his institution was more committed than ever to supporting the culture and people of cinema in circumstances 
... where commercial criteria seem to have become the only ones that preside over cinema exhibition, where the State has only recently started to modify its policy of disdain for artistic endeavor, and an unforgiveable abandonment of the efforts of those filmmakers who with passion and skill have given their time and resources to creativity. ${ }^{2}(1998,11)$

Director of the Cultural Centre Edgar Saba, in his speech at the opening of the first Festival, had flagged this link between cinema and nation with his contention that the event had been borne out of a great affection not only for cinema but also for Peru, proudly highlighting the fact that in such a challenging socio-political and economic context, an academic institution (his own) had come together with a governmental one (PromPerú), an international one (UNESCO) and private enterprise to develop and realize a project such as this. ${ }^{3}(1998,9)$ The sense of unity, collaboration, and commitment to working for a common cause, emerges as the main rallying cry of all the speeches at and reflections on that inaugural event which saw its title develop from being 'a' (un) film festival to ‘the' $(e l)$ festival of cinema in Lima for Latin America: elcine. In his reflection on the event published one year later, critic and academic researcher Carlos Galiano summarized the distinctive features of the festival as being about the coming together of cultural and commercial enterprise adopting the public/private partnership model of most contemporary festivals (Rhyne in Iordanova 1998, 136); involvement of young people at all levels; surprising levels of public participation in the vote for best film; enormous national and international press interest; high level of academic debate across a wide range of topics, the presence and participation of prominent guests from the world of cinema across Latin America. ${ }^{4}(1998,7)$ Indeed, Galiano, Saba and Lerner were united in affirming their belief in cinema’s qualities as expression of cultural identity, as instrument of social change and as signal of economic ambition, and they regarded their event primarily as a place and space for 'screening and discussion of Latin 
American cinema, for encounter and exchange between its creators and spectators, and as a festival of images that unite and give identity' to a region $(1998,7)$. For Saba in particular, there was a sense of urgency relating to equality and justice in his speech, which hinted at something more fundamental about the place of culture in a world of problems and difficult decisions; for him, at that moment in 1997 when Peru was emerging from a terrible civil war, 'Peruvians deserve a film festival, Latin Americans deserve to have the possibility of continuing to produce the best cinema', whatever the circumstances $(1998,9)$.

Having now survived and thrived for almost two decades, this prominent cultural event has also taken on a powerful role as arbiter of quality art cinema and as would-be shaper of cinematic taste, particularly in terms of influencing spectator perspectives on films made by local producers. In this regard, the involvement in the programming of and reporting on the Lima Festival of many of those critics who established Hablemos de Cine (19651985), 'the first and most influential film publication in Peru and the longest-running independent film journal in Latin America’ (Middents 2011, 1) should not be underestimated. ${ }^{5}$ The declared aim of the Festival's organizing committee has always been to screen and celebrate what they believe to have been the best works of the year from the world of independent Latin American cinema. Its choices and exclusions have often been the subject of intense scrutiny by those cultural commentators with concerns that the former Hablemos critics, so tightly associated with this major event, have 'tended to favor productions with an eye toward audiences from Lima, thereby not supporting work from elsewhere in the country' (180). As such, the Festival's programming has risked underscoring and perpetuating the social and political divisions of a nation that remains fragmented along the lines of race, geography and wealth distribution.

As such, the development of this celebration of cinema has, like so many others worldwide, brought with it some controversy, in this case linked to broader concerns around 
the deep-rooted social stratifications and fragmentations in Peru that associate (certain parts of) Lima with the nation's elite and the rest of Peru as marginalized in social, political, cultural and economic terms. For many, the structures of State-sponsored cinema funding and production have done little to challenge or subvert these conditions of power, with the limited resources that have been made available since the launch of a short film fund in the 1970s being awarded mainly to those directors and producers based in Lima and from a privileged educational and social background. This major cultural event might be considered to constitute yet another level of gatekeeping that restricts its benefits to the elite cosmopolitan few, and risks accusations of complying with existing social hierarchies.

While taking account of these apparent intra-national tensions, this essay aims to take a broader approach and explore the extent to which the Lima Film Festival has served as a 'key building block of film culture' (Iordanova 2013, 3), and a marker of cultural pride, in a nation that has otherwise been somewhat overlooked by studies of Latin American and world cinemas more generally. Drawing on the methodological consensus that emerges from the range of writings embraced within Dina Iordanova’s seminal Film Festival Reader (2013, 11), and having located some of its 'key components', or 'unifying concepts' (Turan 2002, 6), as set out by Galiano, Saba and Lerner from the inaugural event, this essay considers how the Lima festival structures, narrates, redefines and continues to find its place in an increasingly crowded festival market. Since visiting Peru in 1998 when, out of serendipity, I met several of the key players in the Peruvian national cinema at the time, and again in 2001 shortly before the Festival took place, I then had the fortune to attend the Lima Film Festival in 2004 and again in 2014. Over this period, while developing research into Peruvian cinema, culture and identity more generally, I have become very interested in the increasingly significant role served by this festival in contributing to the development of a national film culture. This essay reflects on how such deliberations on film culture are 're-enacted in the 
time and space of the festival and even beyond' (Iordanova, 11) and on the linkages and overlaps between this event and some others like it across Latin America. ${ }^{6}$ As Bill Nichols has suggested, festivals are continuous, international arenas for the circulation of films which promote a certain culture of 'traffic in cinema' (in Iordanova 2013, 29), and it is clear that the programmers of the Lima Film Festival have been determined to become an important and recognized space for intersection and interaction between Peruvian, Latin American and world film culture. In summary then, this essay seeks to understand more fully the political, social and economic contribution of the Lima Film Festival to the cultural landscape of Peru, and its relationships with the international world of cinema.

\section{Film Culture in Peru in the 1990s: The Context for the Origins of Lima Film Festival}

When the Lima Film Festival launched, as elcine, in 1997, Peru was just emerging from the horrors and reeling from the aftermath of a political war between the military and insurgent group Shining Path. This was a conflict that disrupted three presidencies (Belaúnde 1980-1985, García 1985-1990 and Fujimori 1990-2000), and devastated indigenous communities, exposing deep rifts between rural and urban, Indian and Hispanic communities and revealing a highly fragmented nation. The violence, which was responsible for almost 70,000 victims on all sides - dead or disappeared - at a time when the country was also in the throes of socio-political and economic collapse, only began to recede when leader Abimael Guzmán was captured and imprisoned in 1992. Supporting any cultural activity, especially one as expensive as film, was hardly a national priority and yet a small number of very prominent productions were realized during this period, including one, La Boca del Lobo/The Lion's Den (Francisco Lombardi, 1988), that has been marked out as the 'representative Peruvian film’ (Middents 2011, 5), and whose director remains Peru’s most internationally renowned filmmaker. His seminal feature portrayed the violence of the Shining Path, and its 
consequences on rural communities, through a compellingly sketched account of a group of soldiers from Lima and their doomed attempt to locate and defeat the enemy in one of the most remote mountainous areas of Peru. Despite having been approved by military chiefs, this film worried the authorities as the timing of its release coincided with a collapse of their counterinsurgency strategy, as well as with a deepening economic crisis that would persist throughout the 1990s. Nevertheless, the film enjoyed critical and public success in Peru, was selected for screening at international festivals throughout Europe, and continues to be included in retrospectives and thematic seasons on the global art cinema circuit. It was also just the sort of film that the most influential critics in Peru of the time - including those who established the aforementioned journal Hablemos de Cine in the 1960s, provide film reviews for all the national newspapers, and who have been members of the Festival Advisory Board since its inception - preferred to highlight, thereby privileging a particular kind of Peruvian cinema with its 'genre-oriented, linear narrative placed in a local setting with careful use of mise-en-scène’' (Middents, 9).

During the 1990s, the worsening economic climate and aftermath of the political violence, including an increasingly oppressive anti-terrorist legislation that affected cultural production as much as other areas of life, gave rise to even more challenging circumstances for cinema activity in Peru where, as John King has noted, 'local film production remained intermittent' (2000, 281). The protectionist Cinema Law established in 1972 to support film production with a range of subsidies and initiatives was repealed in 1992 under Alberto Fujimori’s neo-liberal regime, and a new more market-oriented one introduced only three years later in 1995, after much lobbying, that focused on funding competitions and a new requirement to source match investment. The kind of benefits that had been provided for twenty years, such as tax incentives and guaranteed screenings for films approved by the Ministry of Culture, were entirely absent from the updated proposal. Filmmakers were 
furious at these developments, having themselves put forward a legislative proposal that would have built on the advantages of and addressed some of the problems with the previous one. The disruption brought about by these politically motivated changes was exacerbated by theater closures, declining audiences, rampant DVD and video piracy, as well as by stiff competition from terrestrial and cable television networks. For much of the 1990s, only Lombardi, with his established reputation and ability to attract international investment, was able to keep working and feature film production in Peru all but ground to a halt. As King notes: 'only one Peruvian film [was] released in 1994 and 1995 and none at all in 1997' $(2000,182)$.

And yet, it was precisely in the nadir of 1997 that the elcine festival in Lima was launched, on other one hand perhaps a defiant gesture of support for an art form that was struggling in terms of local production; on the other hand, an initiative entirely in keeping with the developments in film culture in Peru. The Encuentro Latinoamericano de Cine de Lima (Latin American Encounter of Cinema in Lima) was originally conceived as a meeting point for independent Latin American cinema, with specific space for showcasing the work of Peruvian filmmakers. ${ }^{7}$ It has always been hosted by the Catholic University of Peru (PUCP), a cultural and political powerhouse recognized as Peru's most prestigious university and one of the most well-regarded in Latin America as far as research, teaching, partnerships and social responsibility are concerned. ${ }^{8}$ The festival, still held over ten days in the first half of August, comprises of a main program of up to thirty Latin American films selected for competition in documentary and fiction categories, tributes to past and present prominent figures in the global film industry, and other cultural contextual activities such as master classes, lectures and art exhibitions. The award offered by the festival is called 'Trophy Spondylus', a stylized statue of a marine mollusk widely used in the pre-Columbian art of Peru, which creates a formal branding of the event that reveals an intended link to the broader 
political project of nation building through culture. Apparently hesitant at first but taking a lead from other events such as BAFICI (Argentina) which was launched one year after elcine in 1998, from the third edition of the Festival, the program of Peru's main cinema event has welcomed independent cinema from beyond Latin America, with features on directors revered by the critics such as Bruno Dumont (2014). This intertwining of national with regional with international would seem to reflect growing confidence on the part of the event organizers to connect with other festivals, archives and cultural institutions across the world, and a desire to increase the level of ambition and transnational interaction of cinema activity in Peru.

Although the origins of elcine coincided with a period of great difficulty for cinema activity, as the millennium drew to a close, there was a gradual reappearance of locally generated film production that drew funding from private and public sources including transnational schemes such as Ibermedia. By the end of the twentieth century, the modified cinema legislation of 1995, while limited in scope and scale, had begun to reap some rewards: several of the productions that had been in development when the state withdrew suddenly from film funding in 1992 were able, at last, to be completed and screened, and there was renewed interest in short filmmaking, space for which has been a key element of the Lima Film Festival since its inception. Moreover, after 2000 when the Fujimori regime came to an abrupt end and a number of new transnational and international funding opportunities emerged from private and public sources, a group of new Peruvian filmmakers started to make their mark. Although working independently, that's to say, without manifesto or rallying cry from the critics, taken collectively their approaches to cinema marked a distinct shift from the output of the Lombardi generation. As will be explored below, their films deviated from the social realist/genre imperatives of their predecessors and drew on a broader global range of approaches, inspirations and funding schemes. 
The year 2004 (the festival's seventh edition) marked a particularly significant shift with several first-time directors choosing elcine as the forum for their national premiere screenings. For example, Álvaro Velarde, who had recently returned to Peru after gaining education and training in filmmaking in the United States, and who had secured financial support from the Hubert Bals Fund of the International Film Festival Rotterdam, used the Lima Festival as a platform for launching his first feature film, El destino no tiene favoritos/Destiny has no favorites (2003) in Peru. Meanwhile, newcomer Josué Méndez won the critics award and his film collected the Best Actor award that same year with his opera prima Días de Santiago/Days of Santiago (2003), which astonished critics for its technical, artistic and thematic achievements that showed influences of Wong Kar Wei and Martin Scorsese. Worth noting in terms of his acceptance by those critics who had prior to that year ben disdainful of most local production for its mediocre ambitions is that Méndez - who gained his own formative cinema experience more locally through television and theater and participation in workshops run by veteran director Armando Robles Godoy, who had been the guest of honor at the inaugural elcine in 1997 - is now on the Festival's Advisory Committee and a producer of other new directors. Just two years later, the Festival launched the work of, Claudia Llosa, whose films Madeinusa (2006) and La Teta Asustada/Milk of Sorrow (2009) discomforted many Peruvian viewers for their challenging portrayals of indigenous communities, but have satisfied global audiences, critics and funders and achieved significant international success. Indeed her films have triumphed on the international festival circuit, won major awards and nominations including at Berlin and the Oscars, and enjoyed considerable success at commercial art cinemas worldwide having gained international distribution deals. These younger directors, unaccustomed to mechanisms of state support, focused instead on searching out sources of funding and in-kind support beyond the national institutional framework, including schemes offered by other prestigious festivals such as 
Sundance, Rotterdam, Toulouse and Cannes, with their policies of supporting emerging talent from around the world. Tensions abound as a result of this intermingling of the national and the international, with at least some of these directors (Llosa a key example here) accused of making films that are more appreciated by their European funders and audiences, 'clearly marked with nationalist traits that either visually or thematically are recognizable outside the local or national context.' (Middents 2013, 155) Nevertheless, on a pragmatic level, such films and filmmakers have drawn attention to Peruvian cinema as never before, with Llosa's second feature being nominated for the Academy Awards, and with her being invited onto the jury of the Berlin Film Festival (2015). ${ }^{9}$

\section{Resilience and Status: Lima Film Festival 2014}

Having negotiated and survived nearly twenty years of economic, social and political unrest, Lima Film Festival seems to have become a key event on the cultural calendar of Lima and of the world film festival calendar more generally, with increasing numbers of guests from outside Peru, although not yet on the scale of similar events in other Latin American countries. It has developed a clear and consistent programming agenda that stems from its original mission of highlighting those Latin American films that the festival's own advisory committee considers to offer quality in terms of production values, challenging content, and innovations in form, revealing the ways in which the festival's curators, advisors and critics have become attuned to standards and implicit criteria nourished in the international film festival circuit. At the same time, it has served increasingly as a showcase for emerging talent from Peru via short film events all over the city using the cine-club network, and with guests from overseas (from Getino and Sanjinés in 1998, to Dumont in 2014) whose works embrace and contest the ambitions of independence, authenticity and 
innovation that the original festival directors and curators have wanted to become associated with this event. ${ }^{10}$

A brief discussion of the Peruvian films selected for screening in 2014, and their position in this festival's program, reveals more about the aesthetic and thematic preferences and priorities of programmers, funders and critics, and of the shaping of their viewers' tastes, and suggests that there has been a slight rapprochement between national critics and national filmmakers in that more work made in Peru is now showcased by this festival than ever before. For the first time in its history, four of the nineteen fiction feature films and two of the eleven documentaries selected for competition in 2014 were made by or with Peruvian filmmakers, indicating a growth of local activity as well as recognition of the quality and diversity of that activity by the festival's curators. These films included a range of genres and covered topics and locations from across Peru, bringing stories and images from the Amazon rainforest, the cities and the mountain ranges to the cinema screen, and included works by first-time feature directors alongside the more established producers. As has become increasingly the case for Peruvian cinema since the late 1990s, the funding arrangements of these films also reveal the transnational links to other festivals and associated support schemes that allow these works to come to fruition.

On the one hand, the 2014 edition of the Lima Film Festival saw the long-awaited premiere of La cosa/The thing, an abstract comedy by Álvaro Velarde whose previous (debut) feature had been feted by the critics on its premiere in 2004. At that point they felt they had discovered a new Peruvian auteur with a highly distinctive approach that eschewed the emphasis on realism favored by most of his contemporaries, and drew inspiration from the more absurdist approaches of 1930s directors such as Ernst Lubitsch. This much anticipated follow-up had secured very little funding from the Peruvian state competition run by Conacine, the National Committee for Cinema that was part of the Ministry of Culture, 
but it did pick up a script development award from the regional Hispanic funding body Ibermedia. ${ }^{11}$ The film enjoyed moderate success at the Lima Festival, with a devoted audience picking up on its artistic references and verbal nuances, but with no real sign of a life beyond the festival other than at a few niche events in the capital and events such as the Peruvian Film Festival in Paris (2015). Worth noting at this moment is the emphasis placed on a perceived binary between art and commercial cinema by the interviewer from Vértigo Juan Carlos Fangacio (also its overall editor), who insists on categorizing Velarde's work as art and explicitly denying it any commercial potential or populist appeal, despite its comedic values. Although the director agrees that he is more interested in the artistic qualities of cinema, he rejects the idea that art and commercial cinema are exclusive or oppositional categories, and tries to avoid being boxed in by the critics: 'I do believe there is such a thing as "auteur cinema”, and that my work fits into that description; but this is also a comedy, very much a genre film which audiences should enjoy’ explains Velarde (in Fangacio 2014, 6). The permeability of film classification suggested by Nichols in 1994 in relation to the traffic of cinema is recognized here by the director but not so well by the official festival critic whose primary motivation appears to be along the lines suggested by Willemen, that is 'to fix the terms on which films are to make sense' (in Iordanova 2013, 19). This is only an issue in so far as the critic seems to want to understand why Velarde's film style differs so much from his Peruvian predecessors and thus deviates substantially from what had been considered as representing the national.

On the other hand, the Festival edition of 2014 included several screenings of Climas/Climates, a debut drama feature by Enrica Pérez with a tri-partite narrative that explores the lives of women in three different parts of Peru, received support from such initiatives as the PUENTES-BAL production workshop established by BAFICI (Argentina) in 2009, was project winner of the national Conacine competition in 2010 and received 
funding from the transnational Ibermedia scheme. ${ }^{12}$ With its seductive cinematography that fetishizes the harsh beauty of identifiable Peruvian locations (Lima coast, Amazon rainforest, Andean mountains), and specific narrative moments of personal and political crisis that draw attention to national social issues, it fits the rubric of representative Peruvian film as outlined above, and therefore logically works as one of the competition films representing Peruvian cinema in this festival. Moreover, with its broader interpretation of a contemporary female perspective, and adoption of the perennial, cross-national themes of environment as external determinant of personality and coming-of-age amidst adversity, the film also embraces many of the modes of engagement and imaging that Galt and Schoonover (2010) indicate are part of the make-up of global art cinema and fit well on the international festival circuit. In selecting a film such as this, the Lima Festival is aligning itself with others in the region, such as Cartagena in Columbia for example, that promote subjects related to the cultural identity of Latin American countries, the purpose of which being to reinforce a sense of regional identity, celebrate the cultural and audio-visual achievements of the region and to defend the right of citizens to create their own images and tell their own stories through cinema. ${ }^{13}$ Indeed, the interchange of ideas, films and critics between Lima and Cartagena has always been strong, with their shared ideological mission that links the political impulse of the New Latin American Cinema movement of the 1960s with a recognition of the role that regional festivals might now play in supporting local production and global distribution. Moreover, both Lima and Cartagena events appear to fit the description that Rhyne sets out for 'new cosmopolitan cities' that have ambitions to be recognized as 'nodal points in global flows', using their film festivals alongside other cultural events as part of the strategy for doing so (in Iordanova, 139).

In terms of national cinema, the festival of 2014 also included NN by Héctor Gálvez, whose debut feature Paraíso/Paradise (2009) had brought him some success on the global 
circuit (Venice, Miami, Huelva, Cartagena, BAFICI) as well as local recognition as part of the Lima program in 2010 where it won the awards for Best First Film and the Critics Prize. Although this follow-up film focused on topical themes relating to and remaining relevant to the highly specific historical, social and cultural context of the conflict with the Shining Path, and triggered by a very specific moment linked to the work of the Truth and Reconciliation Committee, $N N$ is perhaps a surprising festival choice if one adopts the Nichols model for curating festivals which privileges the artistic and not-generic film, for it works as a crime drama and adopts many of the perennial conventions of that popular genre that 'resonate across historical and cultural boundaries’ (Hjort 2000, 106). Its selection therefore has as much to do with its identity as a Peruvian film, and underscores the Lima Festival's increasing acceptance of the category of the national over the 'exceptional/artistic' (Nichols in Iordanova 1998, 36). While on the one hand, this point itself may seem unexceptional given that each major festival of a particular country promotes current national cinema as well as independent international films, for Lima Festival the greater number of and prominence now afforded to national cinema as part of the event signals a mark of maturity, quality and range of the national offering as well as a sign of confidence on the part of the festival organizers in those films to hold their own as part of an increasingly ambitious program.

Like Climas, this film was also a co-production with Columbia as well as with Germany and France, and was made with the support of Ibermedia and the French government scheme Cinémas du Monde, highlighting the increasingly intrinsic transnational links between festivals and funders that cut through national limitations and emphasizing the complex flow of national/regional/transnational funds and initiatives that challenge the very categories that Lima, like other festivals mentioned here, largely rely upon in order to categorize the films selected for their program. It also marks a further achievement for a 
Peruvian female filmmaker, this time in the guise of its producer Enid 'Pinky' Campos, the driving force behind the success of the aforementioned Days of Santiago (2003), amongst a slate of other highly distinctive works. The presence of this film at Lima Film Festival signals again the desire for this national event to be part of a global circuit that according to Falicov supports 'filmmakers from the global South in production, exhibition and distribution aspects of film and video production' (in Elmer et al 2010, 18), and to use screenings of films that have already gained some international success to develop its own sense of status and profile within the ever-shifting power dynamic of global festivals. As Rhyne points out, and as the discussion of these three films above has shown, 'the play between the local and the global is manifest in the film festival phenomenon' (in Iordanova 1998, 142), with national films using regional, inter and transnational connections to ensure their completion and secure selection as part of the nation's main film festival.

A scan of the programs of the last eighteen years reveals that despite its relative success and survival, the Lima Film Festival has rarely featured the major Latin American releases of the day, lacking the means and the status to outbid its regional and national competitors, many of which would be considered more 'heavyweight' (Iordanova 1998, 118) in what they might offer in terms of exclusivity, reputation and financial reward. Nevertheless, with its foundations during a period of economic austerity and political chaos, and with a curatorial panel made up largely of critics who are influenced by European auteurist cinema of the 1950s and '60s, Lima Film Festival appears to have focused on developing a distinctive reputation that builds on the notion of the 'exceptional' (Nichols, 36) that eschews the major new release. Whether re-introducing classics, offering retrospective strands or presenting restorations of 'forgotten' works, this celebration of cinema incorporates most of the elements that film historian Ian Christie has noted as being crucial to almost all of the 
prestige festivals nowadays, as part of their strategy to avoid having to screen latest works, to enable greater planning, sustainability and participation of third parties, and to work their way up the hierarchical ladder of the global festival circuit (in Acciari and Menarini 2014, $56)$.

Indeed, the range of peripheral events celebrating film culture were stronger than ever in 2014, and it is here that this focus on the local has tended to be strongest. Events included homages to and retrospectives on the work of late prominent figures such as the indigenous actor Aristóteles Picho and producer Stefan Kaspar (Swiss co-founder of the radical Peruvian cinema collective, the Chaski Group ${ }^{14}$ ), again emphasizing the importance of memory to the project of building a sense of national cultural and cinematic identity. It also included a special event to launch a new book about the work of Francisco Lombardi by former Hablemos critic and festival selection committee member Federico de Cárdenas, attended by the director himself; a masterclass by internationally celebrated Peruvian cinematographer Inti Briones; and a presentation of all thirteen of the short films funded in 2014 by the national cinema fund, giving perhaps uneven emphasis to the limited role played by the government in supporting the event. Added to this display of nationally-produced film culture were guests of honor that befitted the auteurist principles of the event: acclaimed French director Bruno Dumont, Mexican filmmaker and self-confessed cinephile Amat Escalante, and North American actor Chaske Spencer, whose latest film Winter in the Blood (Alex and Adam Smith, 2014) was screened as part of a section on Independent US Cinema.

Playing an instrumental role in developing the profile and legacy of the Lima Film Festival is the national film archive, the Filmoteca de Lima, which has since its inception in 1983 been coordinated by the formidable Norma Rivera, another national cinema gatekeeper who is also 
on the Advisory Board of this Festival. In 2014, the contribution of the archive included the screening of the documentary Alerta a la Frontera/Border Alert (Kurt Hermann, 1941), which had been lost for over seventy years, and which provides an account of the 1941 border struggle between Peru and Ecuador. It comprises footage of the conflict filmed by war correspondents and recreations shot by a team from the former Amauta Films, which according to Middents had been 'the first sustained attempt at creating a production company in Peru' (2011, 17). Because of its patriotic tone, the Peruvian government quickly and quietly banned the film from exhibition, claiming not to want to disrupt the peace negotiations with Ecuador that were underway by the start of 1942 (Bedoya 1997, 126). Its reappearance and screening seventy-three years later with the promise of restoration sponsored by the Armed Forces interested in its patriotic qualities, resulted in a politicallycharged screening and discussion involving military, film historians and families of those involved in the conflict, that highlighted the uneasy relationship between cinema, culture, identity and history in Peru. ${ }^{15}$

Although Lima Film Festival has never offered a 'market place' as such, it does place emphasis on inviting and promoting the attendance of guests that include agents, distributors, producers, as well as critics and, increasingly, academics and programmers from other festivals beyond Latin America. Moreover, a brief overview of the funders and supporters of the 2014 festival, many of whom are long-term collaborators, further confirms the continuing importance of the public-private partnership model while also flagging the sometimes uncomfortable interdependence of culture, politics and economics. For example, the Ministry of Culture itself continues to play an influential role through funding (of films screened), hosting of signature events, and curatorial support. Other supporters today include controversial global energy company Petrobras, elitist national daily broadsheet El Comercio, the Grand Theatre which supplies the venue for the opening night, and the BBVA 
Continental Foundation, the philanthropic arm of a principal bank in Peru that prides itself on supporting national art and cultural activities. Partnership arrangements with other major media and telecommunications companies, including Cineplanet, Holá Peru, Plus TV, Titra, Canal N, and ISAT Peru, and overseas cultural supporters such as the French Embassy and the French Institute indicate the high-culture emphasis of the program which remains unknown to the vast majority of Peruvians. Nevertheless, with an eye on an increasingly cineliterate young audience and the possibility of extending its sphere of influence across borders, Festival organizers have embraced the possibilities of social media with activity throughout the year, and have developed the branding and web presence dramatically since 2009 so as to feature the globally recognizable faces of Peruvian and Latin American film actors. From its inception, this festival, like many of its most famous European predecessors, has acted as a 'site for nationalist articulation' alongside a 'forum for international relations, and a function of the commercial cinema market' (Rhyne, 137).

Meanwhile, as evidence of how much part of the establishment Lima Film Festival has become, alternatives and rivals have begun to emerge. For example, the newer Lima Independent International Film Festival has been set up with a mission to disseminate and discuss contemporary independent cinema in Peru. Organized by the Peruvian Independent Cinema Association with the collaboration and support of a range of public and private institutions, this annual event (with much social media activity in-between) serves as a platform to disseminate a riskier, less conventional, more marginal type of cinema - of all forms and formats - than that which is screened at Lima Film Festival. A handful of lowbudget works in digital format had already begun rewriting the history of Peruvian cinema when the first Independent festival was held in 2011, consisting of screenings of more than one hundred films in ten of the smaller cinemas and cine-clubs across Lima. Later editions of the festival have concentrated more on auteur, experimental, expressive and exploratory 
cinema from Peru and around the world, with a diverse range of documentaries, shorts and fiction films screened around the country. I suggest that this gradual proliferation of alternatives points to an acknowledgement of the growing richness and diversity of film culture in Peru and a movement towards a more mature national cinema which functions 'as a mise-en-scène of scattered and dissembling identities’ (Hayward 2000, 101).

Echoing Ragan Rhyne, it does seem that the Lima Film Festival has ceased to be positioned 'at the periphery' of the world cinema stage, and has emerged as an important institutional organism that fits into a much larger national and international network of cultural policy, governance, capitalism and neoliberalism, with a range of complex relationships and partnerships with public and private stakeholders, that does more than 'mediate art and commerce' by in fact managing and maneuvering the interests of its protagonists (in Iordanova 2013, 141). Elcine, known since 2007 as Lima Film Festival, has survived turbulent socio-economic times to establish itself as a flexible geopolitical space within which a range of debates about cinema (specifically) and culture (more generally) take place. Middents has suggested that the viewing position of those who set the tone for cinematic taste in Peru through publications such as Hablemos de Cine and La Gran Ilusión is being confronted 'in much the same way that their elders challenged their own contemporaries forty years earlier' $(2011,14)$, and it is true that the dynamic range of film production activity in, about and across Peru extends way beyond the handful of government and festival-sponsored features that still dominate the attention of audiences and critics of the Lima Film Festival. Nevertheless, I conclude that its intrinsic links with the landmark moments and figures of cinema culture, policy and production in Peru, its birth at the end of one of the most difficult decades for Peruvian society and cinema, and its resilience during some of the toughest years for cinema and nation, make this a powerful event as part of a broader national cultural and international film festival landscape. It looks likely to continue 
to shape the tastes and preferences of local spectators, to influence funders and producers, to provoke the critics, and to support the increased distribution and recognition of independent Peruvian and Latin American films. 


\section{References}

Acciari, Monia and Roy Menarini. 2014. 'Geopolitical Strategies in Film Festivals between Activism and Cinephilia.' Cinergie: Il Cinema e le altre Arti (special edition) 6: 6-56.

Barrow, Sarah. 2007. 'Peruvian Cinema and the Struggle for Recognition.’ In Contemporary Latin American Cinema, edited by Deborah Shaw, 173-189. Lanham: Rowland and Littlefield.

Barrow, Sarah. 2013. 'New configurations for Peruvian cinema: The rising star of Claudia Llosa.' Transnational Cinemas. Volume 4:2, 197-215.

Bedoya, Ricardo. 1997. 100 Años de Cine en el Perú: Una Historia crítica. $2^{\text {nd }}$ edition. Lima: Universidad de Lima.

De Cárdenas, Federico. 2014. El Cine de Francisco Lombardi: Una Visión crítica del Perú. Santiago de Chile: Uzbar Editores.

De Valck, Marijke. 2007. Film Festivals: From European Geopolitics to Global Cinephilia. Amsterdam: Amsterdam University Press.

Falicov, Tamara. 2010. 'Film Festivals and the global south'. In Locating Migrating Media, edited by Greg Elmer, Charles H. Davis, Janine Marchessault, John McCullough, 3-21. Lanham: Rowman \& Littlefield.

Fangacio, Juan Carlos. 2014. 'Álvaro Velarde: Rompiendo Esquemas.’ Vértigo 5: 6. Galiano, Carlos. 1998. 'Una nueva plaza para el cine latinoamericano.’ Memoria del Primer Encuentro Latinoamericano de Cine de Lima, 7. Lima: Universidad Católica del Perú. Galt, Rosalind and Karl Schoonover. 2010. Global Art Cinema: New Theories and Histories. Oxford: Oxford University Press.

Hayward, Susan. 2000. 'Framing National Cinemas.' In Cinema \& Nation, edited by Mette Hjort and Scott Mackenzie, 88-102. London and New York: Routledge. 
Hjort, Mette. 2000. 'Themes of Nation.' In Cinema \& Nation, edited by Mette Hjort and Scott Mackenzie, 103-117. London and New York: Routledge.

Iordanova, Dina. ed. 2013. The Film Festival Reader. St Andrews: St Andrews Film Studies. Iordanova, Dina and Leschu Torchin. eds. 2012. Film Festival Yearbook 4: Film Festivals and Activism. St Andrews: St Andrews Film Studies.

Iordanova, Dina, David Martin-Jones and Belén Vidal. 2010. Cinema at the Periphery. Detroit: Wayne State University Press.

King, John. 2000. Magical Reels: A History of Cinema in Latin America, $2^{\text {nd }}$ ed. New York: Verso.

Lerner Febres, Salomón. 1998. ‘Un compromise para la fiesta future.’ Memoria del Primer Encuentro Latinoamericano de Cine de Lima, 11. Lima: Universidad Católica del Perú. McLennen, Sophie, 2008. 'The theory and practice of the Peruvian Grupo Chaski.' Jump Cut: A review of contemporary media, http://www.ejumpcut.org/archive/jc50.2008/Chaski/. Middents, Jeffrey. 2009. Writing National Cinema: Film Journals and Film Culture in Peru. Lebanon, NH.: University Press of New England.

Middents, Jeffrey. 2013. 'The first rule of Latin American cinema is that you do not talk about Latin American cinema: Notes on discussing a sense of place in contemporary cinema.' Transnational Cinemas. Volume 4:2, 147-164.

Nichols, Bill. 1994. 'Global Image Consumption in the Age of Late Capitalism.' In The Film Festival Reader, edited by Dina Iordanova, 29-44. St Andrews: St Andrews Film Studies. Rhyne, Ragan. 2013. 'Film Festival Circuits and Stakeholders.' In The Film Festival Reader, edited by Dina Iordanova, 135-150. St Andrews: St Andrews Film Studies. Saba, Edgar. 1998. 'Mientras haya luz.' Memoria del Primer Encuentro Latinoamericano de Cine de Lima, 9. Lima: Universidad Católica del Perú. 
Sánchez Prado, Ignacio M. 2014. Screening Neoliberalism: Transforming Mexican Cinema 1988-2012. Nashville: Vanderbilt University Press.

Shohat, Ella and Stam, Robert. 1994. Unthinking Eurocentrism. Abingdon: Routledge. Turan, Kenneth. 2002. Sundance to Sarajevo: Film Festivals and the World they made. Los Angeles and Berkeley: University of California Press.

Vivas, Fernando. 2014. 'El otro sendero for Augusta.’ El Comercio, August 14. http://www.festivaldelima.com/2014/ http://www.pucp.edu.pe/en/about-pucp/our-university/welcome/

\footnotetext{
${ }^{1}$ Those leaders included critic and academic Carlos Galiano, Director of the Cultural Centre Edgar Saba, and Rector of the Catholic University of Peru, Salomón Lerner Febres. ${ }^{2}$ My translation.

${ }^{3}$ The main audience prize of $\$ 10,000$ was sponsored by Cervesur, a well-known national corporation with its roots in the manufacture of beer and with activities that now extend across agriculture, finance, food products and textiles.

${ }^{4}$ Topics of debates at that first event included: ‘Latin American cinema and cultural identity’; 'Latin American cinema: financial options in a market economy’; 'The new communicators; filmmakers for the next millennium'; 'Latin American cinema in the context of the audiovisual industries’. Guests included prominent filmmakers, actors, producers and critics from Mexico, Bolivia, Columbia, Chile, Ecuador and Argentina.

${ }^{5}$ Those critics include Isaac León Frías and Federico de Cárdenas, who were part of the original group of four young men who set up Hablemos de Cine and are still on the Advisory Board of the Festival, as well as Ricardo Bedoya, who joined the publication in 1973 and went on to become the country's only major film historian.
} 
${ }^{6}$ My initial visit in 1998 took place in April of that year when the second edition of the Festival was in its planning stages, and provided opportunities for interviews with some of those who went on to play a key role in its development, such as the director of the national film archive, Norma Rivera. At that point I was working at Cambridge Arts Cinema, which holds an annual film festival of international repute. Subsequent visits have been funded by my university employers (Anglia Ruskin and Lincoln) with the most recent trip also supported by a bursary from the Santander mobility scheme. I would like to take this opportunity to record my gratitude for these opportunities for research and cultural exchange. ${ }^{7}$ In terms of Peruvian cinema, the first edition of the Festival included two national films (out of seventeen) in competition (Bajo la piel/Under the Skin by Lombardi and Ni con dios ni con el diablo/Neither with God nor the Devil by Nilo Pereyra); two special archive presentations (Yo perdí mi corazón en Lima/I lost my Heart in Lima from 1933 by Alberto Santana and Espejismo from 1971 by Armando Robles Godoy); screenings of those short films that had been funded by the Ministry of Culture in 1996 and 1997; and two feature presentations on video (Reportaje a la muerte/Report on Death by Danny Gavidia, and Tupac Amaru by Federico García).

${ }^{8}$ Founded in Lima in 1917, the Catholic University of Peru is noted as one of the twenty-five best universities in Latin America and the only Peruvian university to be listed among the top 500 universities in the world in the international rankings. See http://www.pucp.edu.pe/en/about-pucp/our-university/welcome/ for further details on the institution's achievements and mission, noting that words such as 'prestige', 'leadership' and ‘excellence’ are used to emphasize status.

${ }^{9}$ For a comprehensive discussion of the national and transnational in Latin American cinema, including the role played in this by funders and festivals, see the special issue of Transnational Cinemas devoted to those issues published in 2013. 
${ }^{10}$ As its own daily magazine, Vértigo, pronounced on 8 August 2014: 'Welcome to the eighteenth edition of the Lima Film Festival with a high quality programme ... [and] ... nine days of authentic celebration of cinema' (1).

${ }^{11}$ A full discussion of Alvaro's debut feature and its position on the global film market appears in my essay of 2007, 'Peruvian Cinema and the Struggle for Recognition.' Barrow in Shaw, 173-189.

12 The PUENTES Europe-Latin America Producers Workshop took place in Buenos Aires from March 26-30, 2009 within the framework of the BAFICI (Buenos Aires Festival Internacional de Cine Independiente), supporting five Latin American and five European producers with funding from the EU scheme MEDIA International. At the time of writing, Climas was awaiting the response of the Riviera Lab, FidLab Marseille, World Cinema Fund, and the Buenos Aires Lab, for further support.

${ }^{13}$ The co-producer of Climas was Diana Bustamente, appointed in 2014 as the new director of the Film Festival of Cartagena in Columbia, the oldest festival of its kind, having launched in 1960 .

${ }^{14}$ See Sophie McClennen’s article, 'The theory and practice of the Peruvian Grupo Chaski’, Jump Cut 50, http://www.ejumpcut.org/archive/jc50.2008/Chaski/, 2008, for a full discussion of this group.

${ }^{15}$ The screening of another important film that could not have been made without the input of Peruvian film historians and archivists was Imaginando Mina/Imagining Mina (Alfredo Béjar, 2011), a dramatic story-driven documentary about the Afro-Peruvian boxer Mauro Mina, whose story also reveals much about racism in Peru. 